\title{
SILVER AND/OR COPPER VERMICULITES AND THEIR ANTIBACTERIAL EFFECT
}

\section{Marianna HUNDÁKOVÁ ${ }^{1,2) *}$, Marta VALÁŠKOVÁ ${ }^{1,2)}$, Vladimír TOMÁŠEK ${ }^{1)}$, Erich PAZDZIORA ${ }^{3)}$ and Kateřina MATĚJOVÁ ${ }^{3)}$}

\author{
1) Nanotechnology Centre, VŠB-Technical University of Ostrava, 17. listopadu 15, 70833 Ostrava-Poruba, \\ Czech Republic \\ 2) IT4 Innovations Centre of Excellence, VŠB-Technical University of Ostrava, 17. listopadu 15, \\ 70833 Ostrava-Poruba, Czech Republic \\ 3) National Reference Laboratory, Institute of Public Health in Ostrava, Partyzanske namesti 7 , \\ 70200 Ostrava, Czech Republic \\ *Corresponding author's e-mail: marianna.hundakova@vsb.cz
}

(Received June 2012, accepted November 2012)

\begin{abstract}
Vermiculite (V) from Brazil with aqueous solutions $\mathrm{AgNO}_{3}$ and/or $\mathrm{Cu}\left(\mathrm{NO}_{3}\right)_{2}$ was used for preparation of nanocomposites $\mathrm{V} / \mathrm{Ag}, \mathrm{V} / \mathrm{Cu}, \mathrm{V} / \mathrm{AgCu}$ and $\mathrm{V} / \mathrm{CuAg}$ using two procedures and their effect on bacteria was compared. Structural changes were evaluated using X-ray diffraction (XRD) analysis, Infrared spectroscopy (IRS) and Scanning electron microscopy (SEM). Elemental chemical composition was determined using X-ray fluorescence (XRF) analysis and the solutions were analyzed by Atomic emission spectroscopy with inductively coupled plasma (AES-ICP).

Antibacterial properties of $\mathrm{Ag}$ - and $\mathrm{Cu}$-vermiculites and combined $\mathrm{Ag} / \mathrm{Cu}$-vermiculites were tested on two bacteria groups: (1) Gram-positive, $\mathrm{G}^{+}$, (Staphylococcus aureus and Enterococcus faecalis) and (2) Gram-negative, G', (Pseudomonas aeruginosa and Klebsiella pneumoniae). The samples under antibacterial testing showed different effective times and minimum inhibitory concentration (MIC) values. The Gram-negative bacteria showed higher sensitivity to the prepared samples than Gram-positive bacteria. The combined $\mathrm{Cu} / \mathrm{Ag}$ vermiculites stopped the bacterial growth at lower MIC value.
\end{abstract}

KEYWORDS: vermiculite; silver; copper; structure characterization; antibacterial effect

\section{INTRODUCTION}

Clay mineral vermiculite belongs to a group of planar hydrous phyllosilicates (layered silicates). Vermiculite structure consists from an octahedral sheet placed between two tetrahedral sheets which together form a 2:1 layer. Between the layers is the interlayer space containing hydrated exchangeable cations as an interlayer material. The negative layer charge of vermiculite $0.6-0.9 \mathrm{e}^{-}$resulting from the substitution of $\mathrm{Al}^{3+}$ for the tetrahedral central cation $\mathrm{Si}^{4+}$ and $\mathrm{Al}^{3+}$ and/or $\mathrm{Fe}^{3+}$ for octahedral central cation $\mathrm{Mg}^{2+}$ is balanced by exchangeable cations present in the interlayer (Shirozu and Bailey, 1966; Bailey, 1980; Martin et al., 1991).

Clay minerals have many applications mainly in ceramics as sorbents, catalysts or fillers in various materials, though as well as a matrix for the preparation of metal nanoparticles. The metal nanoparticles can be anchored on the external surface of the clay mineral silicate layers or in their interlayer space.

The most common procedure employed for the preparation of the metal nanoparticles is the reduction from appropriate salts solutions. For example, silver nanoparticles on montmorillonite substrates were prepared using a silver nitrate solution in water (Magaña et al., 2008; Valášková et al., 2007, 2010). Other authors have described procedures, including an additional step of silver nanoparticles' preparation with reducing agents such as sodium borohydride or formaldehyde (Patakfalvi et al., 2003; Praus et al., 2010, Miyoshi et al., 2010), ethylene glycol or glycerol (Ayyppan et al., 1996; Valášková et al., 2007), and also by using UV radiation (Huang and Yang, 2008; Darroudi et al., 2009).

Copper bound on the clay minerals matrix as a hydrate complex can be prepared by cation exchange reaction (Morton et al., 2001; Strawn et al., 2004; Furnare et al., 2005). Drelich et al. (2011) prepared copper nanoparticles on the vermiculite matrix from the cation exchanged $\mathrm{Cu}$-form by hydrogen reduction followed by heat treatment.

Silver and copper are known for their antibacterial properties. Most of authors have studied the antibacterial ability of $\mathrm{Cu}$-forms of montmorillonite (Zhou et al., 2004; Hu et al., 2005; Özdemir et al., 2010) and vermiculite (Li et al., 2002). $\mathrm{Cu}$-montmorillonites were studied in connection with their potential utilization in veterinary medicine (Xia et al., 2005; Hu and Xia, 2006; Tong et al., 2005; Yu et al., 2008). The antibacterial influence of $\mathrm{Ag} /$ montmorillonites and $\mathrm{Ag} /$ vermiculites was less commonly studied (Magaña et al., 2008; Valášková et al., 2010; Özdemir et al., 2010; Malachová et al., 2009). Özdemir et al. (2010) compared the antibacterial effect of $\mathrm{Ag}-\mathrm{Cu}-\mathrm{Cnd} \mathrm{Zn}$ - forms of montmorillonite. The authors have found good antibacterial effect of $\mathrm{Cu}$ - and Ag-montmorillonite 
against bacterial strains Pseudomonas aeruginosa and Staphylococcus aureus.

As described in the previous research works, silver and copper were sporadically studied on the vermiculite. Preparation of the combined content Ag and $\mathrm{Cu}$ on the vermiculite matrix as well as study of their antibacterial effect has not yet been reported. The present work examines the structure and antibacterial effect of $\mathrm{Ag} / \mathrm{Cu}$-vermiculites on the bacteria strains: Gram-positive (Staphylococcus aureus and Enterococcus faecalis) and Gram-negative (Pseudomonas aeruginosa and Klebsiella pneumoniae).

\section{EXPERIMENTAL}

\subsection{MATERIALS}

Vermiculite from Brazil was used as a starting material. The particle size fraction $<40 \mu \mathrm{m}$ was obtained by milling in a planetary mill for $20 \mathrm{~min}$ and sieving by a sieve with a pore size of less than $40 \mu \mathrm{m}$. The half unit cell composition of the vermiculite sample $\left(\mathrm{Si}_{3.08} \mathrm{Al}_{0.92}\right)\left(\mathrm{Mg}_{2.44} \mathrm{Fe}_{0.36}^{3+} \mathrm{Fe}_{0.02}^{2+}\right.$ $\left.\mathrm{Ti}_{0.06} \mathrm{Al}_{0.04}\right) \mathrm{O}_{10}(\mathrm{OH})_{2} \quad \mathrm{~K}_{0.18} \mathrm{Ca}_{0.15} \mathrm{Na}_{0.08}$ was calculated from the results of elemental analysis. Silver nitrate, $\mathrm{AgNO}_{3}$ and copper nitrate, $\mathrm{Cu}\left(\mathrm{NO}_{3}\right)_{2}$ (fy Mach chem., $\mathrm{CZ}$ ) with the purity of $99.99 \%$ were used as sources of silver and copper.

\subsection{SAMPLE PREPARATION}

Four samples were prepared using two procedures: P1, P2:

$\mathrm{P} 1$. Samples $\mathrm{V} / \mathrm{Ag}$ and $\mathrm{V} / \mathrm{Cu}$ were prepared from vermiculite (V) and the 0.1 mol. $\mathrm{dm}^{-3}$ aqueous solution $\mathrm{AgNO}_{3}$ and 0.1 mol.dm ${ }^{-3} \mathrm{Cu}\left(\mathrm{NO}_{3}\right)_{2}$, respectively, at the rate of 1:10 (grams of vermiculite : millilitre of solution), and the suspension was shaken for 24 hours.

$\mathrm{P} 2$. Sample $\mathrm{V} / \mathrm{AgCu}$ was prepared mixing the sample $\mathrm{V} / \mathrm{Ag}$ in the $0.1 \mathrm{~mol} . \mathrm{dm}^{-3}$ aqueous solution $\mathrm{Cu}\left(\mathrm{NO}_{3}\right)_{2}$. Similarly, the sample $\mathrm{V} / \mathrm{CuAg}$ was prepared from the sample $\mathrm{V} / \mathrm{Cu}$ and the $0.1 \mathrm{~mol} . \mathrm{dm}^{-3}$ aqueous solution $\mathrm{AgNO}_{3}$.

All prepared samples were centrifuged and washed with distilled water until nitrate ions were not present, and then dried at $70{ }^{\circ} \mathrm{C}$ for $24 \mathrm{~h}$. The samples with silver were protected before the light by aluminium foil during the preparation.

\subsection{METHODS}

\section{$X$-ray powder diffraction}

The X-ray powder diffraction (XRD) patterns were measured on the X-ray diffractometer from INEL equipped with a $120^{\circ}$ curved position-sensitive detector CPSD 120 (reflection mode, Gemonochromatized $\mathrm{CuK} \alpha_{1}$ radiation). All patterns were recorded at $30 \mathrm{kV}$ and $20 \mathrm{~mA}$, exposure time $2000 \mathrm{~s}$, with the samples in a flat rotation holder.

\section{Scanning electron microscopy}

Morphology and the surfaces of samples were studied using Scanning electron microscopy (SEM) on
PHILIPS XL-30 equipped with energy dispersive spectrometer (EDS) for elemental analysis and mapping.

\section{Fourier transform infrared spectroscopy}

The mid-infrared spectra were obtained by Fourier transform infrared spectroscopy (FTIR) on a Perkin Elmer 2000. The measurement was carried out in the spectral range $4000-400 \mathrm{~cm}^{-1}$ with a resolution of $4 \mathrm{~cm}^{-1}$ at room temperature using the $\mathrm{KBr}$ disc technique.

\section{$X$-ray fluorescence analysis}

The elemental composition of samples and the content of silver and copper were determined by Xray fluorescence elemental analysis (XRF) on an energy dispersive spectrometer SPECTRO X LAB with $\mathrm{Rh} \mathrm{X}$-ray lamp and secondary and polarization targets.

\section{Atomic emission spectroscopy}

Atomic emission spectroscopy with inductively coupled plasma (AES-ICP) on a Jobin-Yvon JY-24 spectrometer was used for determination of elements at leaches after modification.

\subsection{ANTIBACTERIAL TEST}

The antibacterial activity of the prepared nanocomposites was examined using two different groups of experimental bacterial strains. The Gramnegative $\left(\mathrm{G}^{-}\right)$strain represented the bacteria Klebsiella pneumoniae (K. pneumoniae, CCM 4415) and Pseudomonas aeruginosa ( $P$. aeruginosa, CCM 1960). The Gram-positive $\left(\mathrm{G}^{+}\right)$bacterial strain was studied on the bacteria Staphylococcus aureus (S. aureus, CCM 3953) and Enterococcus faecalis (E. faecalis, CCM 4224).

The broth dilution method (Kneiflová, 1988) was used for determination of the minimum inhibitory concentration of silver and/or copper $\left(\mathrm{MIC}_{\mathrm{Ag} / \mathrm{Cu}}\right)$ in samples as the lowest concentration of silver and/or copper that completely inhibits bacterial growth. The bacterial suspension was prepared by a twenty-hour cultivation in glucose broth. The density of the glucose suspension used for individual bacteria was: $S$. aureus $\left(1.0 \times 10^{9} \mathrm{cfu} \mathrm{ml}^{-1}\right), E$ faecalis $\left(1.1 \times 10^{9} \mathrm{cfu} \mathrm{ml}^{-1}\right)$, K. pneumoniae $\left(1.2 \times 10^{9} \mathrm{cfu} \mathrm{ml}^{-1}\right)$, $P$. aeruginosa $\left(1.1 \times 10^{9} \mathrm{cfu} \mathrm{ml}^{-1}\right)$. The silver and copper vermiculite samples were prepared for testing as a $10 \%$ water dispersion, which was further diluted to $3.33 \%, 1.11 \%, 0.37 \%, 0.12 \%$ and $0.041 \%$. The detailed procedure of antibacterial test is published in Valášková et al. (2010).

\section{RESULTS AND DISCUSSION}

\subsection{QUANTITY OF SILVER AND COPPER AT VERMICULITE SAMPLE}

The quantity of silver and copper fixed in vermiculite is given in Table1. Sample V/Ag and $\mathrm{V} / \mathrm{Cu}$ contained the highest content of $\mathrm{Ag}$ and $\mathrm{Cu}$ 
Table 1 The content of silver and copper at vermiculite samples.

\begin{tabular}{llllll}
\hline Sample & $\mathrm{V}$ & $\mathrm{V} / \mathrm{Ag}$ & $\mathrm{V} / \mathrm{Cu}$ & $\mathrm{V} / \mathrm{AgCu}$ & $\mathrm{V} / \mathrm{CuAg}$ \\
\hline \multicolumn{5}{c}{$\left(\mathrm{mmol} \mathrm{g}^{-1}\right)$} \\
$\mathrm{Ag}$ & 0 & 0.52 & 0 & 0.15 & 0.33 \\
$\mathrm{Cu}$ & 0 & 0 & 0.33 & 0.31 & 0.25 \\
\hline
\end{tabular}

(0.52 and $0.33 \mathrm{mmol} . \mathrm{g}^{-1}$, respectively). The content of silver in sample $\mathrm{V} / \mathrm{Ag}$ after the following treatment with $\mathrm{Cu}\left(\mathrm{NO}_{3}\right)_{2}$ solution decreased from 0.52 to $0.15 \mathrm{mmol}^{-1}$ in sample $\mathrm{V} / \mathrm{AgCu}$. Additional treatment $\mathrm{V} / \mathrm{Cu}$ with $\mathrm{AgNO}_{3}$ solution slightly decreased the content of copper from $0.33 \mathrm{mmol} . \mathrm{g}^{-1}$ to $0.25 \mathrm{mmol} . \mathrm{g}^{-1}$ in sample $\mathrm{V} / \mathrm{CuAg}$. The content of silver $0.52 \mathrm{mmol} . \mathrm{g}^{-1}$ in the sample $\mathrm{V} / \mathrm{Ag}$ was reduced to $0.33 \mathrm{mmol} . \mathrm{g}^{-1}$ in $\mathrm{V} / \mathrm{CuAg}$.

These quantity differences resulted from the ways of binding silver and copper cations in vermiculite, and the ability of cations to bind molecules in the interlayer. It was described that (i) the copper on the vermiculite substrate is predominantly positioned in the interlayer where cations are surrounded by water molecules, and also can be adsorbed on hydroxyl edge sites (Clementz et al., 1973; McBride, 1976; Morton et al., 2001) and that (ii) the silver in the interlayer can be present in the form $\mathrm{Ag}^{+}$and also $\mathrm{Ag}^{0}$ without water molecules and on the surface of vermiculite as the silver nanoparticles (Magaňa et al., 2008; Valášková et al., 2007; Tokarský et al., 2010a, 2010b).

The sample $\mathrm{V} / \mathrm{AgCu}$ contained approximately $70 \%$ lower content of silver than the original sample $\mathrm{V} / \mathrm{Ag}$. The sample $\mathrm{V} / \mathrm{CuAg}$ showed a decrease about $25 \%$ of copper in comparison with the original sample $\mathrm{V} / \mathrm{Cu}$. This observation confirmed that the copper was more strongly anchored to vermiculite than silver.

\subsection{CONTENT OF LEACHED ELEMENTS}

The elements released from the vermiculite structure in Table 2 showed the following results: The content of $\mathrm{Na}^{+}$leached from the natural vermiculite was higher in the $\mathrm{AgNO}_{3}$ solution than in the $\mathrm{Cu}\left(\mathrm{NO}_{3}\right)_{2}$ solutions. This finding confirmed cation exchange of $\mathrm{Na}^{+}$for $\mathrm{Ag}^{+}$and is in agreement with observations reported in literature (Rivera-Garza et al., 2000; de la Rosa Gomez et al., 2008). Similarly, the higher divalent $\mathrm{Ca}^{2+}$ exchanged for $\mathrm{Cu}^{2+}$ was confirmed by higher content of $\mathrm{Ca}^{2+}$ determined after treatment in the $\mathrm{Cu}\left(\mathrm{NO}_{3}\right)_{2}$ solution than in the $\mathrm{AgNO}_{3}$ solution. It was also observed that the solution $\mathrm{Cu}\left(\mathrm{NO}_{3}\right)_{2}$ contributed to the release not only of divalent cations $\mathrm{Ca}^{2+}$ and $\mathrm{Mg}^{2+}$ but also $\mathrm{Si}^{4+}$ from tetrahedra.
Table 2 Concentration of elements at solution leached from vermiculite.

\begin{tabular}{lrrcrc}
\hline Sample & \multicolumn{1}{c}{$\mathrm{Na}$} & $\mathrm{K}$ & $\mathrm{Mg}$ & $\mathrm{Ca}$ & $\mathrm{Si}$ \\
\hline & \multicolumn{5}{c}{$\mathrm{mmol.}^{-1}$} \\
\cline { 2 - 6 } $\mathrm{V} / \mathrm{Ag}$ & 15.65 & 1.69 & 12.76 & 2.15 & 0.21 \\
$\mathrm{~V} / \mathrm{AgCu}$ & 2.57 & 3.94 & 8.2 & 1.78 & 1.64 \\
$\mathrm{~V} / \mathrm{Cu}$ & 12.26 & 2.89 & 18.93 & 13.33 & 2.39 \\
$\mathrm{~V} / \mathrm{CuAg}$ & 1.13 & 2.66 & 9.18 & 3.58 & 1.71 \\
\hline
\end{tabular}

\subsection{X-RAY DIFFRACTION ANALYSIS}

The XRD pattern of the original V (Fig. 1) shows the intensive basal diffraction with $d(001)=$ $1.42 \mathrm{~nm}$. The interlayer space value corresponds to the two-layer hydrate phase (Walker, 1956). The other two low-intensive and broad diffractions with $d=1.24 \mathrm{~nm}$ and $d=2.32 \mathrm{~nm}$ match the one-layer hydrate domains and mix-layered water molecules domains, respectively (Marcos et al., 2009).

Exfoliation of the layered vermiculite structure resulted in a decrease in the intensities of the basal diffractions. If we consider the observed integral intensity of basal reflection (001) with $d(001)=$ $1.42 \mathrm{~nm}$ for $\mathrm{V}$ as $100 \%$ (relative intensity), we can calculate the percentage decrease in the relative intensity of (001) reflection to $73 \%$ at $\mathrm{V} / \mathrm{Cu}$ (Fig. 1b) and to $9 \%$ in $\mathrm{V} / \mathrm{Ag}$ (Fig. 1e). The next broad diffraction with $d=1.24 \mathrm{~nm}$ in $\mathrm{V}$ shifted to the smaller interlayer space (e.g. to the $d=1.1 \mathrm{~nm}$ in $\mathrm{V} / \mathrm{AgCu}$ ) and proved formation of mixtures of less hydrated phases. The metal silver was observed only on the XRD pattern of the sample V/Ag as low intensive diffractions $d(111)=0.236 \mathrm{~nm}$ and $d(200)=$ 0.204 nm (Fig. 1e).

\subsection{INFRARED SPECTROSCOPY}

The IR spectra of the samples in Figure 2 showed the shift of the stretching vibration of water $\mathrm{O}-\mathrm{H}$ groups at $3420 \mathrm{~cm}^{-1}$ in $\mathrm{V}$ to $3440 \mathrm{~cm}^{-1}$ in $\mathrm{V} / \mathrm{Ag}$ and to $3446 \mathrm{~cm}^{-1}$ in $\mathrm{V} / \mathrm{CuAg}$.

In the case of samples $\mathrm{V} / \mathrm{Cu}, \mathrm{V} / \mathrm{CuAg}$ and $\mathrm{V} / \mathrm{AgCu}$, this band at $3420 \mathrm{~cm}^{-1}$ became wide and the new bands at $3527 \mathrm{~cm}^{-1}$ and $3549 \mathrm{~cm}^{-1}$ appeared, and are probably associated with $\mathrm{Cu}$-for-Mg substitution (Farmer and Russell, 1964). The band $1646 \mathrm{~cm}^{-1}$ belongs to the deformation vibrations of the water $\mathrm{O}$ $\mathrm{H}$ groups. The shift of this band was, in sample $\mathrm{V} / \mathrm{AgCu}$, to $1635 \mathrm{~cm}^{-1}$, contrary to the $\mathrm{V} / \mathrm{CuAg}$, where the new band at $1541 \mathrm{~cm}^{-1}$ indicated different coordinated water forms, probably owing to the type of the interlayer cations (Madejová, 2003). Accordingly, in our samples the wavenumbers shifts depend on the type of predominant cation in the interlayer. The band at $1002 \mathrm{~cm}^{-1}$ belongs to the stretching vibrations of Si-O-Si. The band at $812 \mathrm{~cm}^{-1}$ was ascribed to the bending vibrations of hydroxyl groups shared between $\mathrm{Al}^{3+}$ and $\mathrm{Mg}^{2+}$ ions (Farmer and Russell, 1964); the band at $739 \mathrm{~cm}^{-1}$ are the 


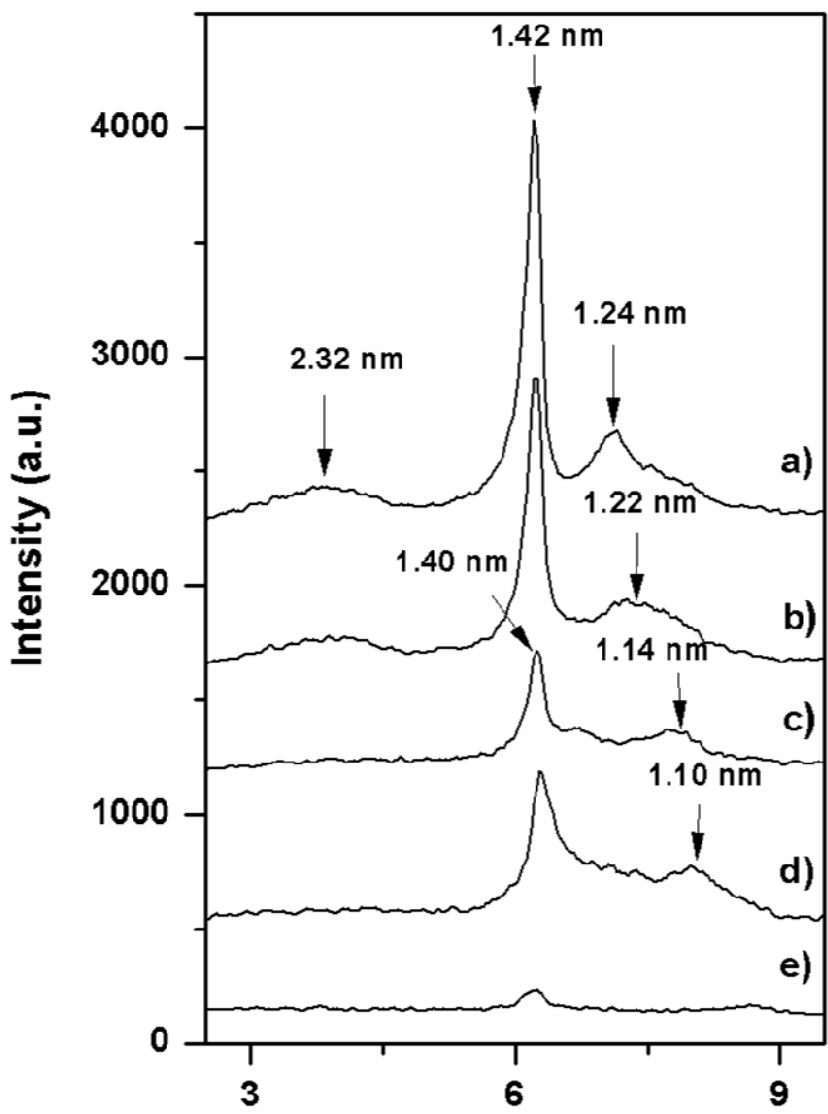

$2 \theta(\mathrm{CuK} \alpha)\left(^{\circ}\right)$

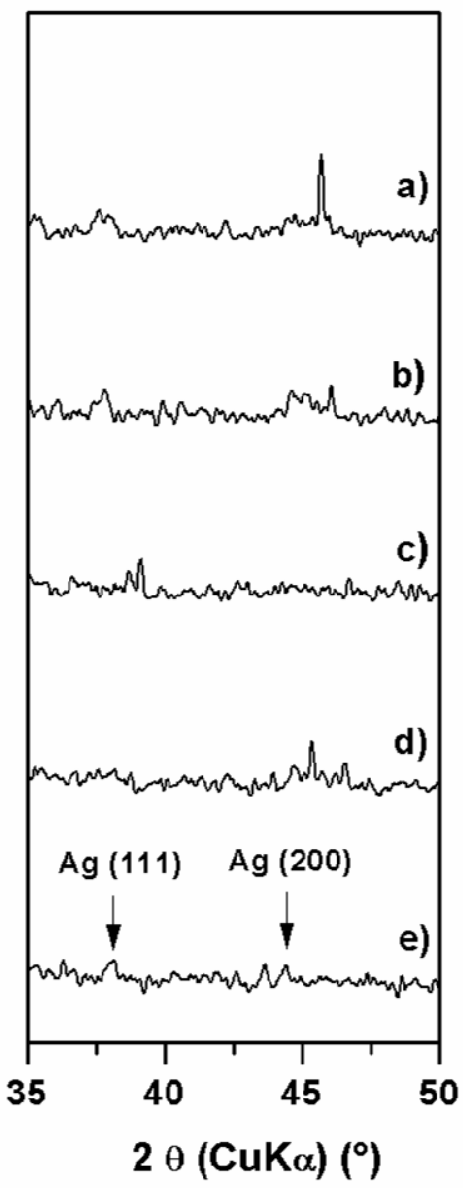

$2 \theta(\mathrm{CuK} \alpha)\left({ }^{\circ}\right)$

Fig. 1 The XRD patterns of basal diffractions (from $2^{\circ}$ to $10^{\circ} 2 \theta$ ) and $\mathrm{Ag}$ diffractions (from $35^{\circ}$ to $50^{\circ} 2 \theta$ ) of $\mathrm{V}(\mathrm{a}), \mathrm{V} / \mathrm{Cu}(\mathrm{b}), \mathrm{V} / \mathrm{CuAg}(\mathrm{c}), \mathrm{V} / \mathrm{AgCu}(\mathrm{d})$ and $\mathrm{V} / \mathrm{Ag}(\mathrm{e})$.

bending vibrations of tetrahedral Si-O. The position shifted from $685 \mathrm{~cm}^{-1}$ at $\mathrm{V}$ to the slightly lower vibrations $683 \mathrm{~cm}^{-1}$ at $\mathrm{V} / \mathrm{Cu}, \mathrm{V} / \mathrm{CuAg}$ and $\mathrm{V} / \mathrm{AgCu}$ involves bending vibrations of $\mathrm{Mg}_{3} \mathrm{OH}$ and $\mathrm{Mg}_{2} \mathrm{AlOH}$ (Farmer, 1974; Madejová, 2003). The band around $458 \mathrm{~cm}^{-1}$ was assigned to bending vibrations Si-O-M (where $\mathrm{M}$ can be $\mathrm{Si}, \mathrm{Mg}, \mathrm{Al}$ or $\mathrm{Fe}$ ) (Van der Marel and Beutelspacher, 1976).

\subsection{SCANNING ELECTRON MICROSCOPY}

The images of the samples with the spot elemental analysis are shown in Figures 3 and 4. The characteristic lamellar morphology of vermiculite was, after treatment, partially disturbed. The treatment with $\mathrm{Cu}\left(\mathrm{NO}_{3}\right)_{2}$ solution caused the vermiculite flakes change to the flocky aggregates (Fig. 3c).

\subsection{ANTIBACTERIAL ACTIVITY}

The samples under antibacterial test showed different effective times and $\mathrm{MIC}_{\mathrm{Ag} / \mathrm{Cu}}$ values (Tables 3 and 4). The sample V/Ag had a positive effect against the $\mathrm{G}^{-}$bacteria and stopped bacterial growth after $24 \mathrm{~h}\left(\mathrm{MIC}_{\mathrm{Ag}}=0.21 \mathrm{mg} . \mathrm{l}^{-1}\right)$. The sample $\mathrm{V} / \mathrm{Cu}$ also showed the positive effect for all bacteria regarding $\mathrm{MIC}\left(\mathrm{MIC}_{\mathrm{Cu}}=0.69 \mathrm{mg} . \mathrm{l}^{-1}\right)$ and short effective time of $5 \mathrm{~h}$ to suspend bacterial growth. The sample $\mathrm{V} / \mathrm{AgCu}$ after $24 \mathrm{~h}$ showed the lowest
MIC from all of the samples on the $\mathrm{G}^{-}$bacteria $P$. aeruginosa $\left(\mathrm{MIC}_{\mathrm{Ag} / \mathrm{Cu}}=0.06 / 0.07 \mathrm{mg} . \mathrm{l}^{-1}\right)$. On the other hand the $\mathrm{V} / \mathrm{CuAg}$ was the most effective in stopping bacterial grow of $\mathrm{G}^{+}$bacteria - S. aureus $\left(\mathrm{MIC}_{\mathrm{Ag} / \mathrm{Cu}}=0.13 / 0.06 \mathrm{mg} . \mathrm{l}^{-1}\right)$ after $24 \mathrm{~h}$.

The difference of activity of bacteria $\mathrm{G}^{+}$and $\mathrm{G}^{-}$are caused by structural variations of their cell walls. While the $\mathrm{G}^{-}$bacteria have an outer membrane layer of cells formed by lipopolysacharides and phospholipids, and only a thin layer of peptidoglycan, the $\mathrm{G}^{+}$bacteria cell is composed of many layers of peptidoglycan and lipoteichoic acid. The $\mathrm{G}^{+}$bacteria cell is simpler and more resistant, probably thanks to a rough layer of peptidoglycan.

Distinct action of $\mathrm{Ag}$ and $\mathrm{Cu}$ on bacteria was ascribed to several mechanisms (Abad et al., 1994; Tong et al., 2005). Both elements can be attached by the negatively charged bacterial cell and disturb the cell walls and permeability and react with sulphurand phosphorus- groups of enzymes, proteins and DNA as well. These metals can also cause oxidative stress by generation of hydroxide radicals (Samuni et al., 1981; Thurman and Gerba, 1989). The increased negative effect of combined $\mathrm{Ag}, \mathrm{Cu}$ - vermiculites on bacteria could be ascribed to their synergic effect on bacteria (Lin et al., 1996). 


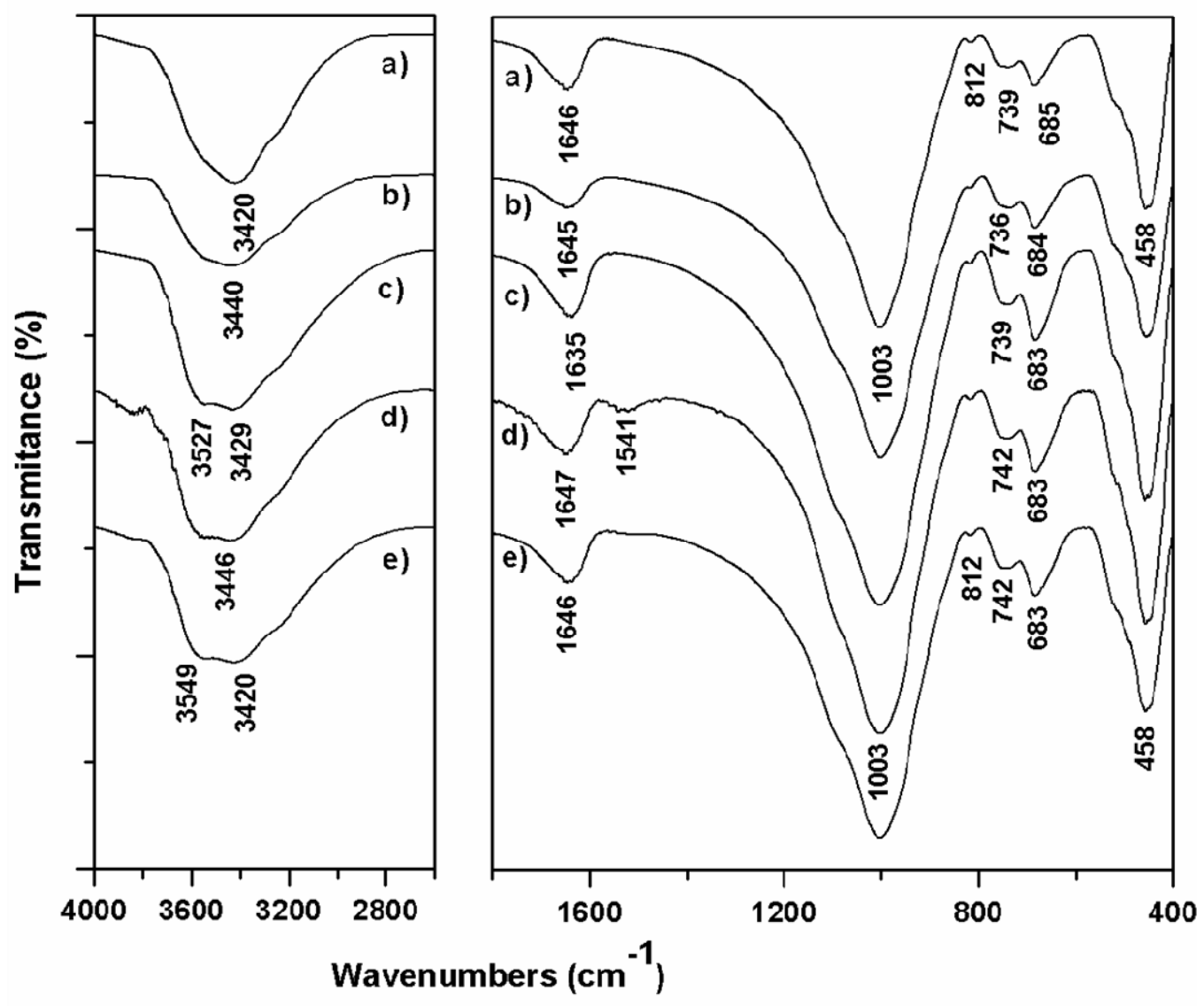

Fig. 2 The infrared spectra from 4000 to $2600 \mathrm{~cm}^{-1}$ and from 1800 to $400 \mathrm{~cm}^{-1}$ of V (a), $\mathrm{V} / \mathrm{Ag}(\mathrm{b}), \mathrm{V} / \mathrm{AgCu}(\mathrm{c}), \mathrm{V} / \mathrm{CuAg}(\mathrm{d})$ and $\mathrm{V} / \mathrm{Cu}(\mathrm{e})$.

\section{CONCLUSIONS}

In this study the antibacterial vermiculites with $\mathrm{Ag}$ and/or $\mathrm{Cu}$ were prepared and characterized. Vermiculite layered structure after treatment with $\mathrm{AgNO}_{3}$ and/or $\mathrm{Cu}\left(\mathrm{NO}_{3}\right)_{2}$ became the mixtures of differently hydrated layers domains.

The sample V/Ag showed the highest content of Ag. Samples $\mathrm{V} / \mathrm{Cu}$ and $\mathrm{V} / \mathrm{AgCu}$ contained the highest amount of $\mathrm{Cu}$.

The natural vermiculite had no effect on bacteria growth. The Gram negative $P$. aeruginosa and $K$. pneumoniae were more sensitive to sample $\mathrm{V} / \mathrm{Cu}$ than to the $\mathrm{V} / \mathrm{Ag}$, and the antibacterial effect was observed after $5 \mathrm{~h}$ and $24 \mathrm{~h}$, respectively. Combined $\mathrm{Cu} / \mathrm{Ag}$ vermiculites stopped the bacterial growth at lower MIC values. The Gram negative $P$. aeruginosa growth was inhibited after $24 \mathrm{~h}$ at the lowest concentration of the sample $\mathrm{V} / \mathrm{AgCu}$ when the MIC of the $\mathrm{Ag}$ and $\mathrm{Cu}$ was $0.06 \mathrm{mg} . \mathrm{l}^{-1}$ and $0.07 \mathrm{mg} . \mathrm{l}^{-1}$, respectively. The Gram positive bacteria $S$. aureus was the most sensitive to the sample $\mathrm{V} / \mathrm{CuAg}$ and inhibited growth after $24 \mathrm{~h}$ at the lowest MIC of $\mathrm{Ag}$ and $\mathrm{Cu}$ of $0.13 \mathrm{mg} . \mathrm{l}^{-1}$ and $0.06 \mathrm{mg} \cdot \mathrm{l}^{-1}$. Gram positive E. faecalis stopped growth after $48 \mathrm{~h}$ action of sample $\mathrm{V} / \mathrm{Cu}$ (MIC of $\mathrm{Cu} 0.69 \mathrm{mg} . \mathrm{l}^{-1}$ ).

\section{ACKNOWLEDGEMENTS}

This work was supported by projects: Ministry of education, Youth and Sport of Czech Republic
SP2012/43, the Czech Grant Agency GA ČR P210/11/2215 and the IT4Innovations Centre of Excellence project reg. no.cz.1.05/1.1.00/02.0070.

The authors thank to J. Seidlerová for ICP-AES analysis, M. Heliová and S. Kozubová for SEM images, S. Holešová for IR spectra and D. Casten for linguistic correction of the text.

\section{REFERENCES}

Abad, F.X., Pintó, R.M., Diez, J.M. and Bosch, A.: 1994, Disinfection of human enteric viruses in water by copper and silver in combination with low levels of chlorine. Appl. Environ. Microbiol., 60, 2377- 2383.

Ayyappan, S., Subbanna, G.N., Gopalan, R.S. and Rao, C.N.R.: 1996, Nanoparticles of nickel and silver produced by the polyol reduction of the metal salts intercalated in montmorillonite. Solid State Ionics, 84, 271-281. DOI: 10.1016/0167-2738(96)00021-5

Bailey, S.W.: 1980, Summary of recommendations of AIPEA nomenclature committee on clay minerals. Am. Mineral., 65, 1-7.

Clementz, D.M., Pinnavaia, T.J. and Portland, M.M.: 1973, Stereochemistry of hydrated copper (II) ions on the interlamellar surfaces of layer silicates. An electron spin resonance study. J. Phys. Chem., 77, 196-200. DOI: $10.1021 / \mathrm{j} 100621 \mathrm{a} 010$

Darroudi, M., Ahmad, M.B., Shameli, K., Abdullah, A.H., Ibrahim, N.A.: 2009, Synthesis and characterization of UV-irradiated silver/montmorillonite nanocomposites. Solid State Sci., 11, 1621-1624. DOI: $10.1016 /$ j.solidstatesciences.2009.06.016

De la Rosa-Gomez, I., Olguina, M.T. and Alcantara, D.: 2008, Antibacterial behavior of silver-modified 

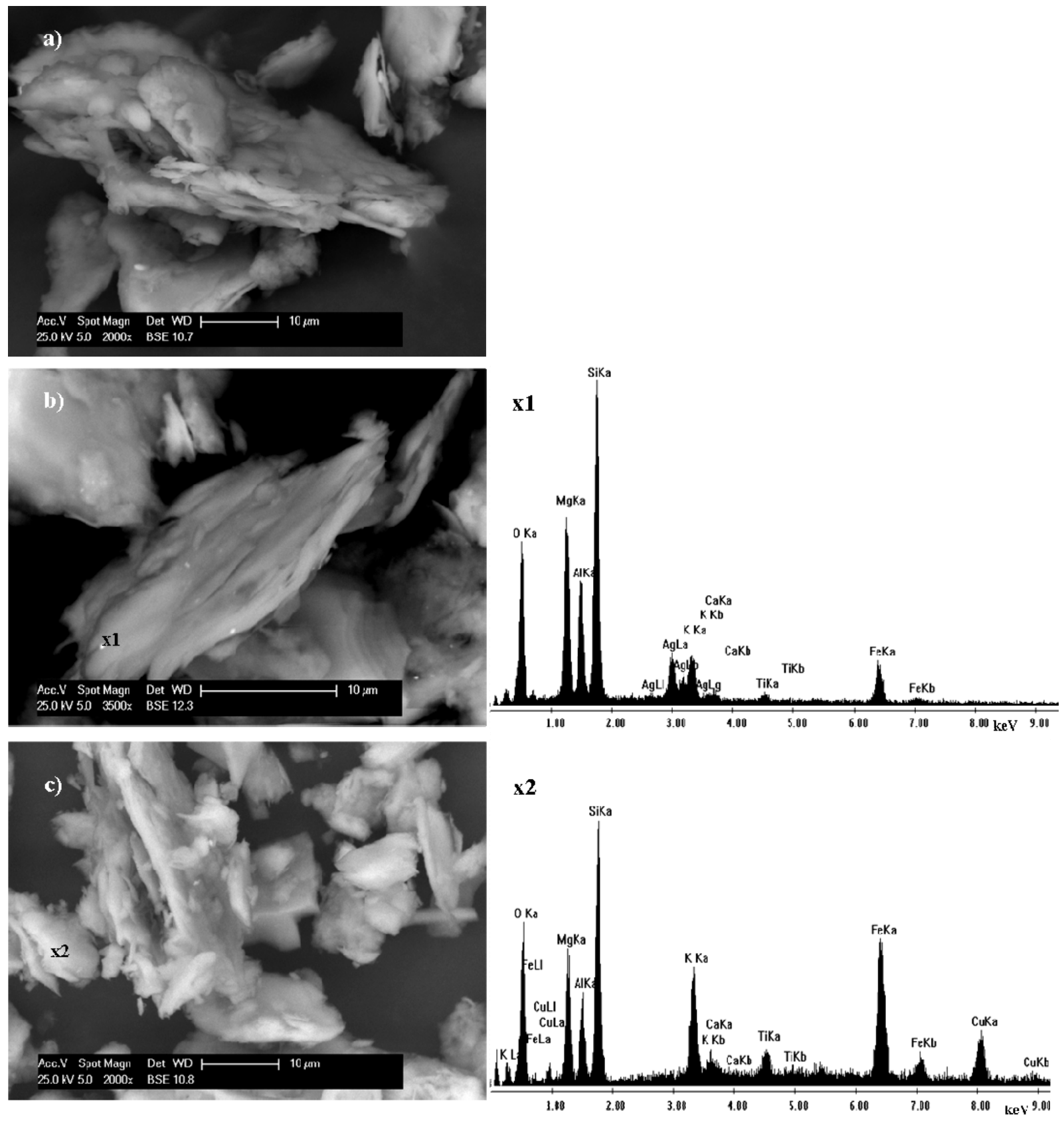

Fig. 3 SEM images of $\mathrm{V}(\mathrm{a}), \mathrm{V} / \mathrm{Ag}(\mathrm{b})$ and $\mathrm{V} / \mathrm{Cu}(\mathrm{c})$ and their spectrum of spot elemental analysis.

Table 3 The results of antibacterial test for the Gram-positive bacteria.

\begin{tabular}{lcccccc}
\hline Bacteria & \multicolumn{3}{c}{ S. aureus $\left(\boldsymbol{G}^{+}\right)$} & & & E. faecalis $\left(\boldsymbol{G}^{+}\right)$ \\
\hline & Dilution & $\mathrm{MIC}_{\mathrm{Ag} / \mathrm{Cu}}$ & time & Dilution & $\mathrm{MIC}_{\mathrm{Ag} / \mathrm{Cu}}$ & time \\
\cline { 2 - 7 } Sample & $(\%)$ & $\left(\mathrm{mg} . \mathrm{l}^{-1}\right)$ & $(\mathrm{h})$ & $(\%)$ & $\left(\mathrm{mg} .1^{-1}\right)$ & $(\mathrm{h})$ \\
$\mathrm{V}$ & - & - & - & & - & - \\
$\mathrm{V} / \mathrm{Ag}$ & 1.11 & $0.62 / 0.00$ & 24 & 1.11 & $0.62 / 0.00$ & 72 \\
$\mathrm{~V} / \mathrm{Cu}$ & 3.33 & $0.00 / 0.69$ & 24 & 3.33 & $0.00 / 0.69$ & 48 \\
$\mathrm{~V} / \mathrm{CuAg}$ & 0.37 & $0.13 / 0.06$ & 24 & 3.33 & $1.18 / 0.52$ & 24 \\
$\mathrm{~V} / \mathrm{AgCu}$ & 3.33 & $0.55 / 0.66$ & 48 & 3.33 & $0.55 / 0.66$ & 72 \\
\hline
\end{tabular}



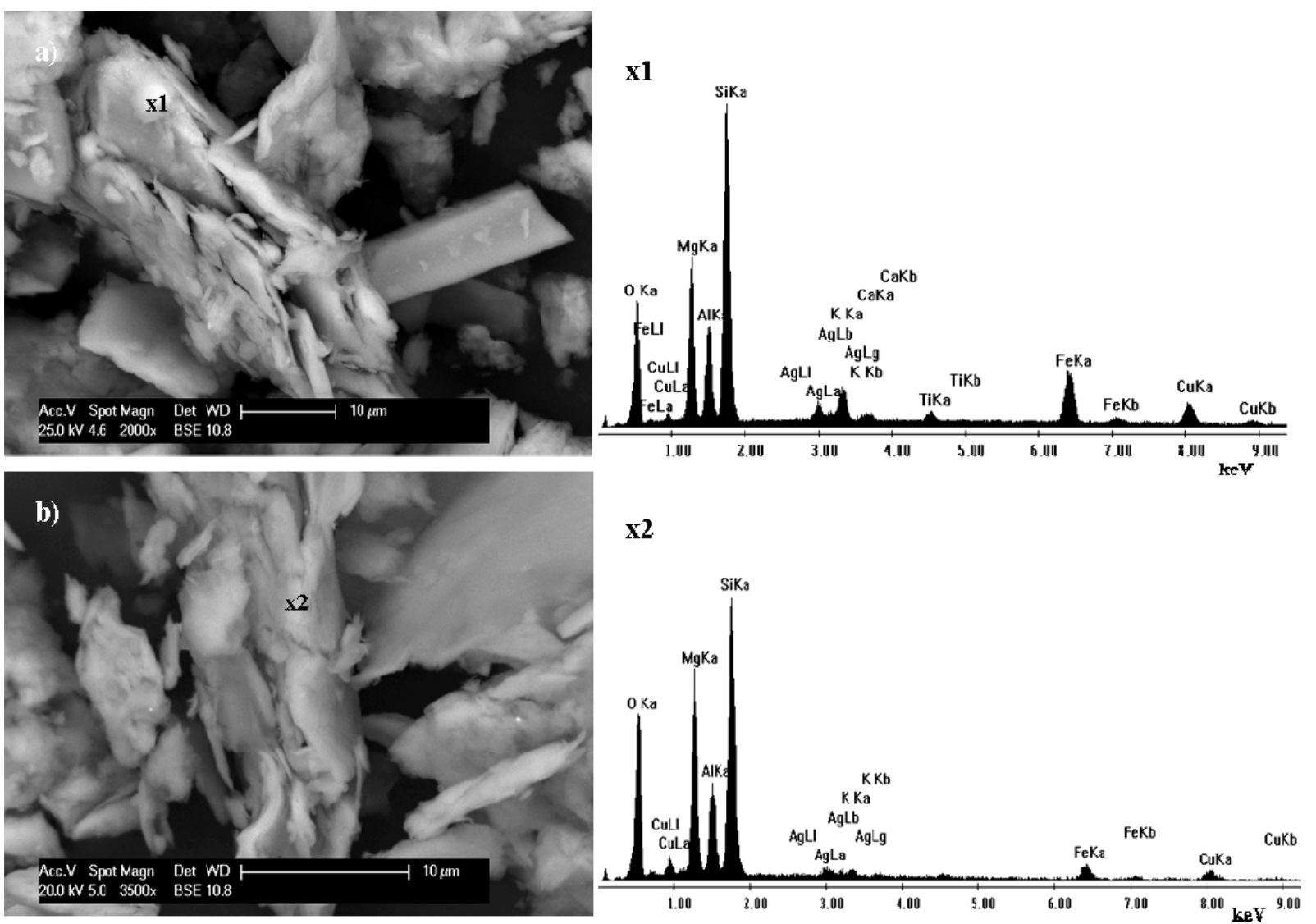

Fig. 4 SEM images of $\mathrm{V} / \mathrm{AgCu}(\mathrm{a})$ and $\mathrm{V} / \mathrm{CuAg}(\mathrm{b})$ and their spectrum of spot elemental analysis.

Table 4 The results of antibacterial test for the Gram-negative bacteria.

\begin{tabular}{lcccccc}
\hline Bacteria & \multicolumn{3}{c}{$\boldsymbol{P .}$ aeruginosa $\left(\boldsymbol{G}^{-}\right)$} & \multicolumn{3}{c}{ K. pneumoniae $\left(\boldsymbol{G}^{-}\right)$} \\
\hline \multirow{2}{*}{ Sample } & Dilution & $\mathrm{MIC}_{\mathrm{Ag} / \mathrm{Cu}}$ & time & Dilution & $\mathrm{MIC}_{\mathrm{Ag} / \mathrm{Cu}}$ & time \\
\cline { 2 - 7 } $\mathrm{V}$ & $(\%)$ & $\left(\mathrm{mg.}^{-1}\right)$ & $(\mathrm{h})$ & $(\%)$ & $\left(\mathrm{mg} . \mathrm{l}^{-1}\right)$ & $(\mathrm{h})$ \\
$\mathrm{V} / \mathrm{Ag}$ & - & - & - & & - & - \\
$\mathrm{V} / \mathrm{Cu}$ & 0.37 & $0.21 / 0.00$ & 24 & 0.37 & $0.21 / 0.00$ & 24 \\
$\mathrm{~V} / \mathrm{CuAg}$ & 3.33 & $0.00 / 0.69$ & 5 & 3.33 & $0.00 / 0.69$ & 5 \\
$\mathrm{~V} / \mathrm{AgCu}$ & 1.11 & $0.39 / 0.17$ & 24 & 1.11 & $0.39 / 0.17$ & 5 \\
\hline
\end{tabular}

clinoptilolite-heulandite rich tuff on coliform microorganisms from wastewater in a column system. J. Env. Man., 88, 853-863.

DOI: $10.1016 /$ j.jenvman.2007.04

Drelich, J., Li, B., Bowen, P., Hwang, J.-Y., Mills, O. and Hoffmann, D.: 2011, Vermiculite decorated with copper nanoparticles: Novel antibacterial hybrid material. A. Surf. Sci., 257, 9435-9443.

DOI: 10.1016/j.apsusc.2011.06.027

Farmer, V.C.: 1974, The Infrared Spectra of Minerals. Monograph 4, Mineralogical Society, London.

Farmer, V.C. and Russell, J.D.: 1964, The infrared spectra of layer silicates. Spectrochim. Acta, 20, 1149-1173. DOI: 10.1016/0371-1951(64)80165-X

Furnare, L.J., Vailionis, A. and Strawn, D.G.: 2005, Molecular-level investigation into copper complexes on vermiculite: Effect of reduction of structural iron on copper complexation. J. Colloid. Interface Sci., 289, 1-13. DOI: $10.1016 /$ j.jcis.2005.03.068

Hu, C.H. and Xia, M.S.: 2006, Adsorption and antibacterial effect of copper-exchanged montmorillonite on Escherichia coli K88. Appl. Clay Sci., 31, 180-184. DOI:10.1016/j.clay.2005.10.010

Hu, C.H., Xu, Z.R. and Xia, M.S.: 2005, Antibacterial effect of $\mathrm{Cu}^{2+}$-exchanged montmorillonite on Aeromonas hydrophila and discussion on its mechanism. Vet. Microbiol., 109, 83-88.

DOI: 10.1016/j.vetmic.2005.04.021

Huang, H. and Yang, Y.: 2008, Preparation of silver nanoparticles in inorganic clay suspensions. Compos. Sci. Technol., 68, 2948-2953.

DOI:10.1016/j.compscitech.2007.10.003

Kneiflová, J.: 1988, Evaluation of the antibacterial effect of disinfectants using a suspension micro-method 
(Hodnocení baktericidní účinnosti dezinfekčních prostředků suspenzní mikrometodou). Čs. epidemiologie, mikrobiologie a imunologie, 37, 97104, (in Czech)..

Li, B., Yu, S., Hwang, J.Y. and Shi, S.: 2002, Antibacterial vermiculite nano-material. J. Miner. Mater. Char. Eng., 1, 61-68.

Lin, Y.E., Vidic, R.D., Stout, J.E. and Yu, V.L.: 1996, Individual and combined effects of copper and silver ions on inactivation of Legionella Pneumophila. Wat. Res., 30, 1905-1913. DOI: $10.1016 / 0043-1354(96) 00077-2$

Madejová, J.: 2003, FTIR techniques in clay mineral studies. Vib. Spectrosc., 31, 1-10. DOI: 10.1016/S0924-2031(02)00065-6

Magaña, S.M., Quintana, P., Aquilatr, D.H., Toledo, J.A., Ángeles-Chávez, C., Cortés, M.A., León, L., FreilePelegrín, Y., Lopt, T. and Torres Sánchez, R.M.: 2008, Antibacterial activity of montmorillonites modified with silver. J. Mol. Catal. A: Chem., 281, 192-199. DOI: 10.1016/j.molcata.2007.10.024

Malachová, K., Praus, P., Pavlíčková, Z. and Turicová, M.: 2009, Activity of antibacterial compounds immobilised on montmorillonite. Appl. Clay Sci., 43, 364-368. DOI: 10.1016/j.clay.2008.11.003

Marcos, C., Arango, Y.C. and Rodriguez, I.: 2009, X-ray diffraction studies of the thermal behaviour of commercial vermiculites. Appl. Clay Sci., 42, 368378. DOI: 10.1016/j.clay.2008.03.004

Martin, R.T., Bailey, S.W., Eberl, D.D., Fanning, D.S., Guggenheim, S., Kodama, H., Pevear, D.R. Šrodoň, J. and Wicks, F.J.: 1991 Report of the clay minerals society nomenclature committee: Revised classification of clay materials. Clays Clay Miner., 39, 333-335. DOI: 10.1346/CCMN.1991.0390315

McBride, M.: 1976, Hydration structure of exchangeable $\mathrm{Cu}^{2+}$ in vermiculite and smectite. Clays Clay Min., 24, 211-212. DOI: 10.1346/CCMN.1976.0240410

Miyoshi, H., Ohno, H., Sakai, K., Okamura, N. and Kourai, H.: 2010, Characterization and photochemical and antibacterial properties of highly stable silver nanoparticles prepared on montmorillonite clay in nhexanol. J. Colloid. Interface Sci., 345, 433-441. DOI: $10.1016 /$ j.jcis.2010.01.034

Morton, J.D., Semnu, J.D. and Hayes, K.F.: 2001, An X-ray absorption spectroscopy study of the structure and reversibility of copper adsorbed to montmorillonite clay. Geochim. Cosmochim. Acta, 65, 2709-2722. DOI: $10.1016 / \mathrm{S} 0016-7037(01) 00633-0$

Özdemir, G., Limoncu, M.H. and Yapar, S.: 2010, The antibacterial effect of heavy metal and cetylpridiniumexchanged montmorillonites. Appl. Clay Sci., 48, 319-323. DOI: 10.1016/j.clay.2010.01.001

Patakfalvi, R., Oszkó, A. and Dékány, I.: 2003, Synthesis and characterization of silver nanoparticle/kaolinite composites. Colloid. Surf. A: Physicochem. Eng. Asp., 220, 45-54. DOI: $10.1016 / \mathrm{S} 0927-7757(03) 00056-6$

Praus, P., Turicová, M., Machovič, V., Študentová, S. and Klementová, M.: 2010, Characterization of silver nanoparticles deposited on montmorillonite. Appl. Clay Sci., 49, 341-345. DOI: 10.1016/j.clay.2010.06.009

Rivera-Garza, M., Olguín, M.T., García-Sosa, I., Alcántara, D. and Rodríguez-Fuentes, G.: 2000, Silver supported on natural Mexican zeolite as an antibacterial material, Micropor. Mesopor. Mater., 39, 431-444.

DOI: 10.1016/S1387-1811(00)00217-1

Samuni, A., Chevion, M. and Czapski, G.: 1981, Unusual copper-induced sensitization of the biological damage due to superoxide radicals. J. Biol. Chem., 256, 12632-12635.

Shirozu, H., Bailey, S.W.: 1966, Crystal structure of a twolayer Mg-vermiculite. Am. Mineral., 51, 1124-1143.

Strawn, D.G., Palmer, N.E., Furnare, L.J., Goodell, C., Amonite, J.E. and Kukkadapu, R.K.: 2004, Copper sorption mechanisms on smectites. Clays Clay Miner., 52, 321-333. DOI: 10.1346/CCMN.2004.0520307

Thurman, R. and Gerba, C.: 1989, The molecular mechanisms of copper and silver ion disinfection of bakteria and viruses. Crit. Rev. Env. Contr., 18, 295315 .

Tokarský, J., Čapková, P., Klemm, V., Rafaja, D. and Kukutschová, J.: 2010a, Adhesion of silver nanoparticles on the montmorillonite surface. J. Phys. Chem. Sol., 71, 634-637.

DOI: 10.1016/j.jpcs.2009.12.055

Tokarský, J., Čapková, P., Rafaja, D., Klemm, V., Valášková, M., Kukutschová, J. and Tomášek, V.: 2010b, Adhesion of silver nanoparticles on the clay substrates; modeling and experiment. Appl. Surf. Sci., 256, 2841-2848. DOI: 10.1016/j.apsusc.2009.11.037

Tong, G., Yulong, M., Peng, G. and Zirong, X.: 2005, Antibacterial effects of the $\mathrm{Cu}(\mathrm{II})$-exchanged montmorillonite on Escherichia coli K88 and Salmonella choleraesuis. Vet. Microbiol., 105, 113122. DOI: 10.1016/j.vetmic.2004.11.003

Valášková, M., Hundáková, M., Mamulová Kutláková, K., Seidlerová, J., Čapková, P., Pazdziora, E., Matějová, K., Heřmánek, M., Klemm, V. and Rafaja, D.: 2010, Preparation and characterization of antibacterial silver/vermiculites and silver/montmorillonites. Geochim. Cosmochim. Acta, 74, 6287-6300. DOI: $10.1016 /$ j.gca.2010.08.025

Valášková, M., Simha Martynková, G., Lešková, J., Čapková, P., Klemm, V. and Rafaja, D.: 2007, Silver nanoparticles/Montmorillonite composites prepared using nitrating reagent at water and glycerol. J. Nanosci. Nanotechnol., 8, 1-9. DOI: 10.1166/jnn.2008.088

Van der Marel, H.W. and Beutelspacher, H.: 1976, Atlas of infrared spectroscopy of clay minerals and their admixtures. Elsevier Scientific Publishing Company, Amsterdam.

Walker, G. F.: 1956, Mechanism of dehydration of Mgvermiculite. Clays Clay Min., 4, 101-115.

Xia, M.S., Hu, C.H. and Xu, Z.R.: 2005, Effects of copper bearing montmorillonite on the growth performance, intestinal microflora and morphology of weanling pigs. Anim. Feed Sci. Tech., 118, 307-317. DOI: $10.1016 / j$.anifeedsci.2004.11.008

Yu, D.Y., Li, X.L. and Li, W.F.: 2008, Effect of Montmorillonite Superfine Composite on Growth Performance and Tissue Lead Level in Pigs. Biol. Trace Elem. Res., 125, 229-235. DOI: $10.1007 / \mathrm{s} 12011-008-8173-0$

Zhou, Y., Xia, M., Ye, Y. and Hu, C.: 2004, Antimicrobial ability of $\mathrm{Cu}^{2+}$-montmorillonite. Appl. Clay Sci., 27, 215-218. DOI: 10.1016/j.clay.2004.06.002 